\title{
PERSPECTIVES
}

\section{ALTERNATIVE MEANS OF FUNDING CONTINUING MEDICAL EDUCATION: A SRI LANKAN EXPERIENCE}

\author{
Rajeewa Dassanayake \\ District General Hospital Polonnaruwa \\ Contact: Dr. Rajeewa Dassanayake \\ Email: rajeewa_d@yahoo.com, (i) https://orcid.org/0000-0002-3870-6362
}

The effects of interaction between the pharmaceutical industry and physicians are a global concern. A recent meta analysis has described associations between such interactions and prescribing patterns and quality ${ }^{1}$. Studies have shown that exposure to information provided directly by pharmaceutical industry was either associated with inappropriately increased and lower quality prescribing, or showed no association. No evidence of net improvements in prescribing was found ${ }^{1,2}$. Pharmaceutical industry funding of continuing medical education (CME) is controversial. A large survey found that $88 \%$ of CME participants believed commercially motivated sponsorships introduced bias, but only a minority were willing to accept increased participation costs $^{3}$. Thus, accepting pharmaceutical funding may raise ethical issues, while denial may increase cost, and reduce participation. In 2017, the Polonnaruwa Clinical Society conducted its annual academic sessions without pharmaceutical sponsorships, and was totally free of charge for participants. Our experience may be of interest to other providers of continuing medical education in Sri Lanka.

Several countries have national codes of conduct for interaction with the pharmaceutical industry.
Levels of hospitality should not exceed what recipients would choose when paying themselves. Any gifts should be of limited financial value and relevant to doctors' work. Venues should not be selected for their leisure and recreational facilities. International guidelines by the World Health Organization and others are available for countries that do not have national guidelines ${ }^{4}$. Many writers have suggested a ban on pharmaceutical sponsorship of $\mathrm{CME}^{5}$.

In 2017, the Polonnaruwa Clinical Society took a decision to not accept pharmaceutical sponsorships for its activities. The annual academic sessions were conducted in December. The inauguration ceremony was held at hotel Sudu Araliya. The Polonnaruwa Medical Journal was launched at this event. The main sessions were conducted in the Maithreepala Sirisena auditorium at the Polonnaruwa General Hospital. Free papers were presented by regional and external authors. Eminent speakers from many parts of the country attended. Accommodation was made available to all speakers if required, at hotel Sudu Araliya. Meals, stationary and souvenirs were provided for all participants. No fee of any kind was charged. 
Funding was obtained from individual and cooperate well wishers. With the exception of the state pharmaceuticals cooperation, no funding was obtained from pharmaceutical companies. Almost all the funds were provided by regional businesses and regional branches of larger organisations. We explained that CME was essential to maintain quality of patient care. Contributions were made willingly and enthusiastically. Fund raising was not a difficult task.

My president's message was as follows; "The theme for the annual academic sessions of the Polonnaruwa Clinical Society this year is "a quest for professionalism and integrity". In a landmark paper in 2006, Professor Blumenthal and colleagues called on academic medical centres in the United States to end the direct drug company sponsorship of continuing medical education events. As calls to end drug companies' direct sponsorship of doctors' education echo round the world, I am proud to welcome you to the second annual academic sessions of the Polonnaruwa Clinical Society, which have been organized without funding from any parties with potential conflicts of interests. I sincerely hope that this effort will serve as a guiding light to others in Sri Lanka, who wish to embark on a quest to maintain the integrity of our profession."

This may be the first time that a regional medical body in Sri Lanka conducted annual academic sessions without pharmaceutical sponsorships. Our experience has shown that this is possible, at least with regard to regional $\mathrm{CME}$ events.

\section{References}

1. Brax H, Fadlallah R, Al-Khaled L, Kahale L A, Nas H, El-Jardali F, Akl E A. Association between physicians' interaction with pharmaceutical companies and their clinical practices: A systematic review and metaanalysis. PLoS ONE. 2017; 12(4): e0175493.

http://doi.org/10.1371/journal.pone.0175 $\underline{493}$

2. Spurling GK, Mansfield PR, Montgomery BD, Lexchin J, Doust J, Othman N, Vitry AI. Information from Pharmaceutical Companies and the Quality, Quantity, and Cost of Physicians' Prescribing: A Systematic Review. PLoS Med. 2010: 7(10): e1000352.

https://doi.org/10.1371/journal.pmed.10 $\underline{00352}$

3. Tabas JA, Boscardin C, Jacobsen DM, Steinman MA, Volberding PA, Baron RB. Clinician Attitudes About Commercial Support of Continuing Medical Education. Results of a Detailed Survey. Arch Intern Med. 2011; 171(9):840-846.

https://doi.org/10.1001/archinternmed.2 $\underline{011.179}$

4. Wager E. How to dance with porcupines: rules and guidelines on doctors' relations with drug companies. BMJ: British Medical Journal, 2003:326(7400):1196-1198. https://doi.org/10.1136/bmj.326.7400.11 $\underline{96}$

5. Spithoff, S. Industry involvement in continuing medical education: Time to say no. Canadian Family Physician. 2014; 60(8):694-696. 